\title{
MACRODACTYLY OF LOWER LIMBS-AN UPDATE
}

\author{
Mariappan Natarajan ${ }^{1}$, Subha Dhua², Cheena Garg ${ }^{3}$
}

${ }^{1}$ Associate Professor, Department of Plastic Surgery, Vydehi Institute of Medical Sciences and Research Centre, Bengaluru. ${ }^{2}$ Associate Professor, Department of Plastic Surgery, Vydehi Institute of Medical Sciences and Research Centre, Bengaluru. ${ }^{3}$ Assistant Professor, Department of Pathology, Vydehi Institute of Medical Sciences and Research Centre, Bengaluru.

\begin{abstract}
Congenital macrodactyly is a rare congenital malformation characterized by progressive enlargement of all mesenchymal elements of a digit. The most characteristic finding noted was excessive overgrowth of fibrofatty tissue with unusually large fatty lobules fixed by a mesh of dense fibrous tissue. Hypertrophy and tortuosity of the digital nerve, a striking feature in macrodactyly of the hand was notably absent in cases affecting the foot. Most of the cases are reported as isolated anomalies. In macrodactyly of the foot, excessive proliferation and accumulation of adipose tissue was the basic lesion whereas involvement of the nerve is the fundamental lesion in gigantism of the hand. The final pathway of genesis of these anomalies must be either the local deficiency of a growth inhibiting factor or local expression of a basic intrinsic factor leading to excessive growth of all elements of the digit.
\end{abstract}

\section{KEYWORDS}

Macrodactyly, Congenital, Reconstruction, Island Nail Flap, Deformity, Localized Gigantism, Macrodystrophia Lipomatosa.

HOW TO CITE THIS ARTICLE: Natarajan M, Dhua S, Garg C. Macrodactyly of lower limbs-an update. J. Evolution Med. Dent. Sci. 2016;5(55):3806-3810, DOI: 10.14260/jemds/2016/871

\section{INTRODUCTION}

Literal translation of the term macrodactyly is "large digit" that presents as an overgrowth of entire digit. Other names for this condition are localized hypertrophy, local gigantism, and megalodactyly. Barsky's definition of macrodactyly states that phalanges, tendons, nerves, vessel, subcutaneous fat, finger nails, and skin must all be enlarged.[1] This overgrowth condition can affect one or multiple digits of the upper or lower extremities. Fingers are involved more frequently than toes. The deformity can present unilaterally or bilaterally.

Hypertrophy of only skin and soft tissue alone does not constitute primary macrodactyly and they are classified as secondary macrodactyly. Congenital overgrowth disorders of the lower extremity have been reported in podiatric literature since the 1980s. The advancements in genetics and diagnostic imaging have made better understanding of these conditions. The aetiologies of overgrowth conditions are largely unclear. Macrodactyly of the foot is usually an isolated entity.[2] The deformity is often progressive with less neural involvement than in hand macrodactyly.[3] Pedal macrodactyly can be difficult to treat surgically and multiple surgical interventions may be needed. The goal of surgical intervention in macrodactyly is to achieve an aesthetically and functionallyacceptable limb. Common complaints by patients with macrodactyly of foot include difficulty in walking, inability to fit in normal shoe gear, stiff toes, toe nail irritation, distal ulcers, osteomyelitis, and cosmetic concerns. This condition is physically and emotionally debilitating. Years of discomfort and frustration on part of the adult patients drives them to opt for amputation rather than salvage techniques.

Financial or Other, Competing Interest: None.

Submission 30-03-2016, Peer Review 07-06-2016,

Acceptance 13-06-2016, Published 11-07-2016.

Corresponding Author:

Dr. N. Mariappan,

B-011, B Block, Rsun Palms,

Ramanagondanahalli to Borewell Road,

Whitefield. Bangalore-560066.

Karnataka, India.

E-mail:drn_m@hotmail.com

DOI: $10.14260 / \mathrm{jemds} / 2016 / 871$

\section{Clinical Case Presentation}

A 2 years old first male child born of non-consanguineous parents presented with enlargement of the left big toe, second and third toes of the foot. The parents noticed the enlargement at the time of birth and have been progressively increasing rapidly out of proportion to the growth of the child. Clinical examination showed enlargement of the big toe with deformity. There was syndactyly between the second and third toes with fusion of the nail complexes.
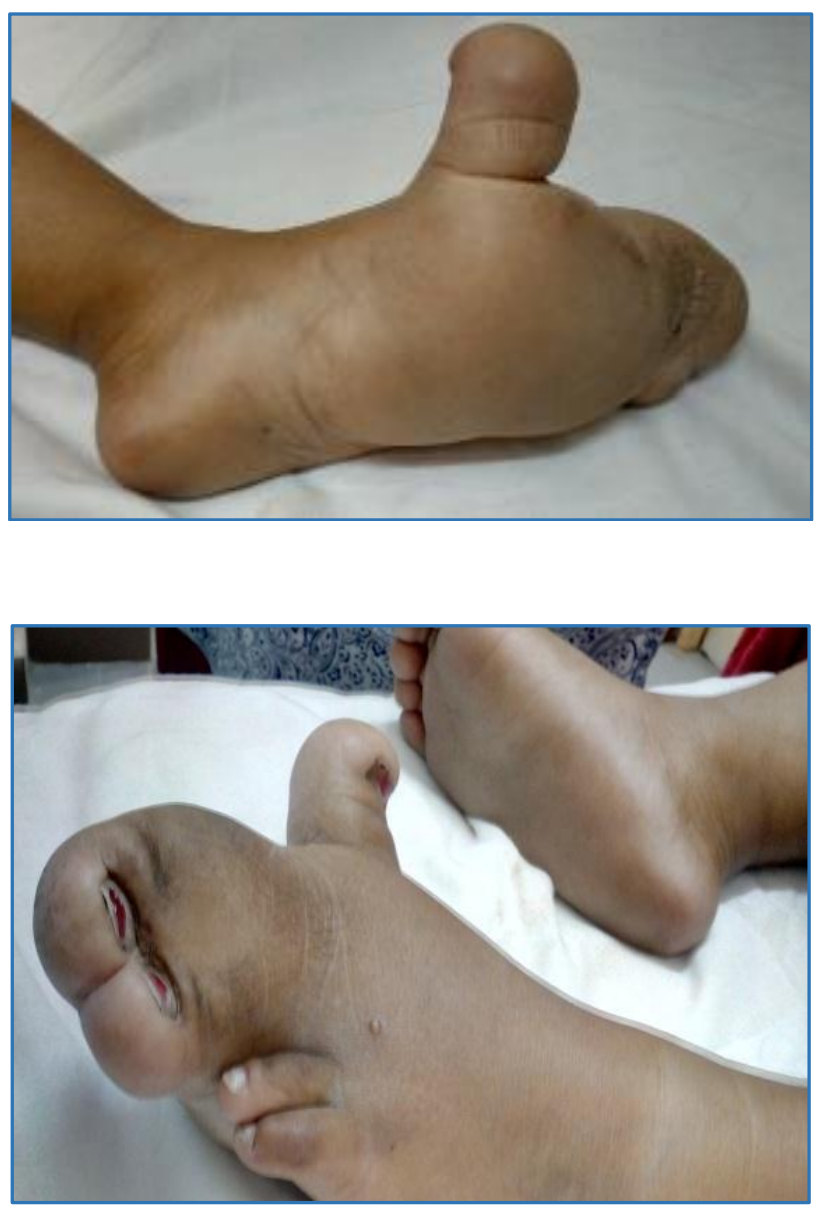


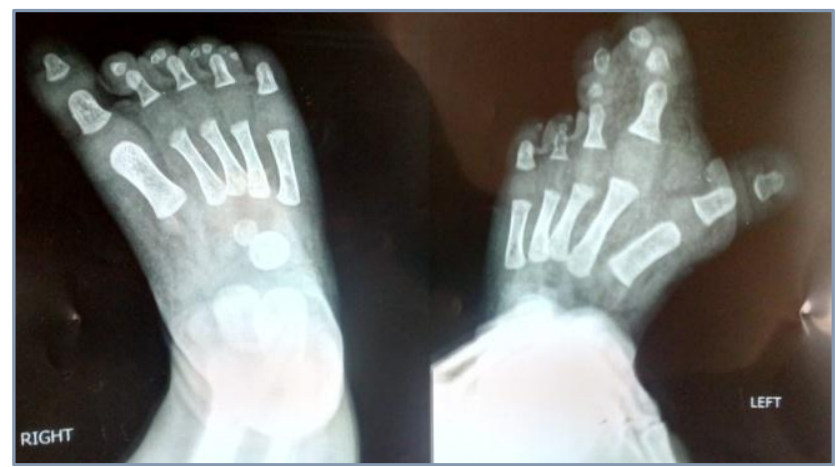

Fig. 1: Macrodactyly of the Left Foot Shows Enlarged Big Toe, Second and Third Toes. Syndactyly between the Second and Third Toes is seen. Plain X-Ray of Both Feet Shows Larger-Sized Phalanges of the Involved Digits

The swelling was confined more to the plantar aspect of the foot and more at the distal parts of the digits. X-ray of the left foot showed enlargement of soft tissue and phalanges of the left big toe, second and third toes. There was fusion of the terminal phalanges of the second and third toes and fusion of the nail complex. The metatarsals were normal and the right foot bony architecture is normal. (Figure.1). The patient was planned for surgery. Under general anaesthesia and tourniquet control, ray amputation of the second and third toes was done. Cut section of the amputated part showed soft tissue and bone enlargement. The digital nerves were found to be of normal size. (Figure: 2).

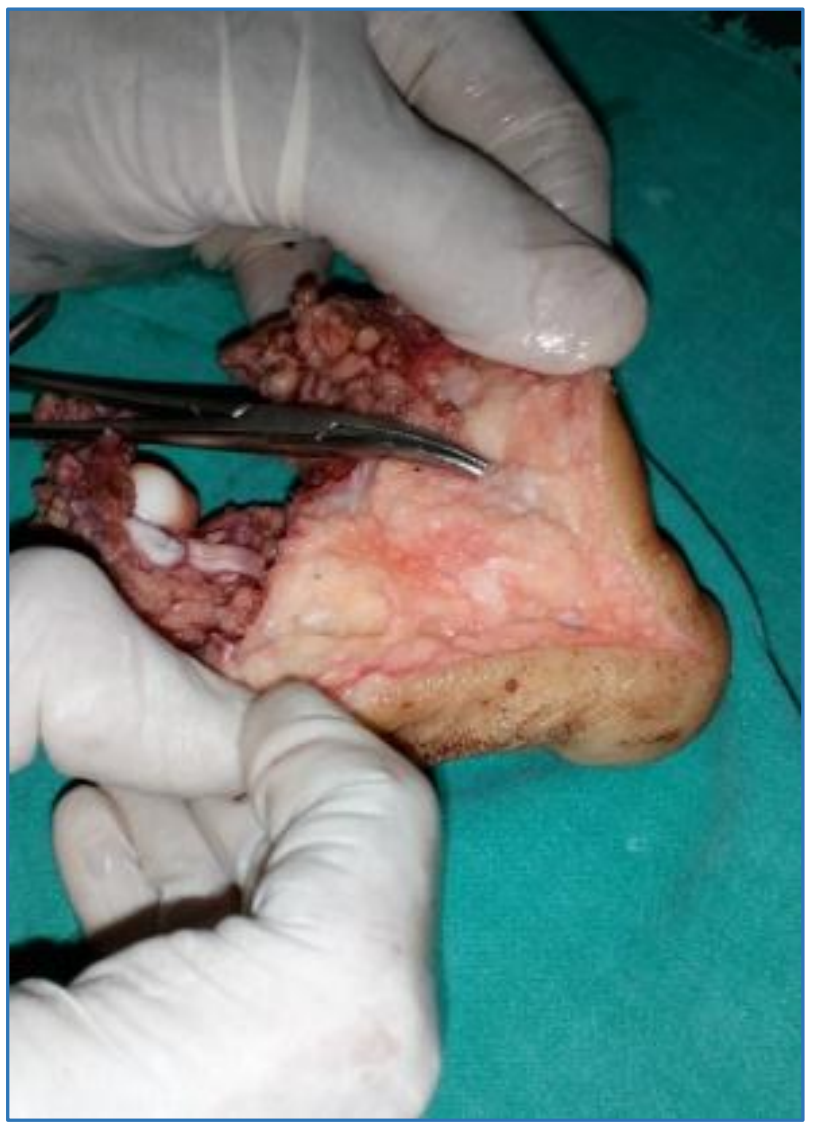

Fig. 2: Cut Section of the Amputated Toes Showed Enlargement of all the Mesenchymal Elements With Normal Size of the Digital Nerves
Histopathological examination showed excessive proliferation of subcutaneous adipose tissue with increased fibrous septae with thinning of the epidermis [Figure. 3] with enlarged bony component and normal calibre of nervous elements.
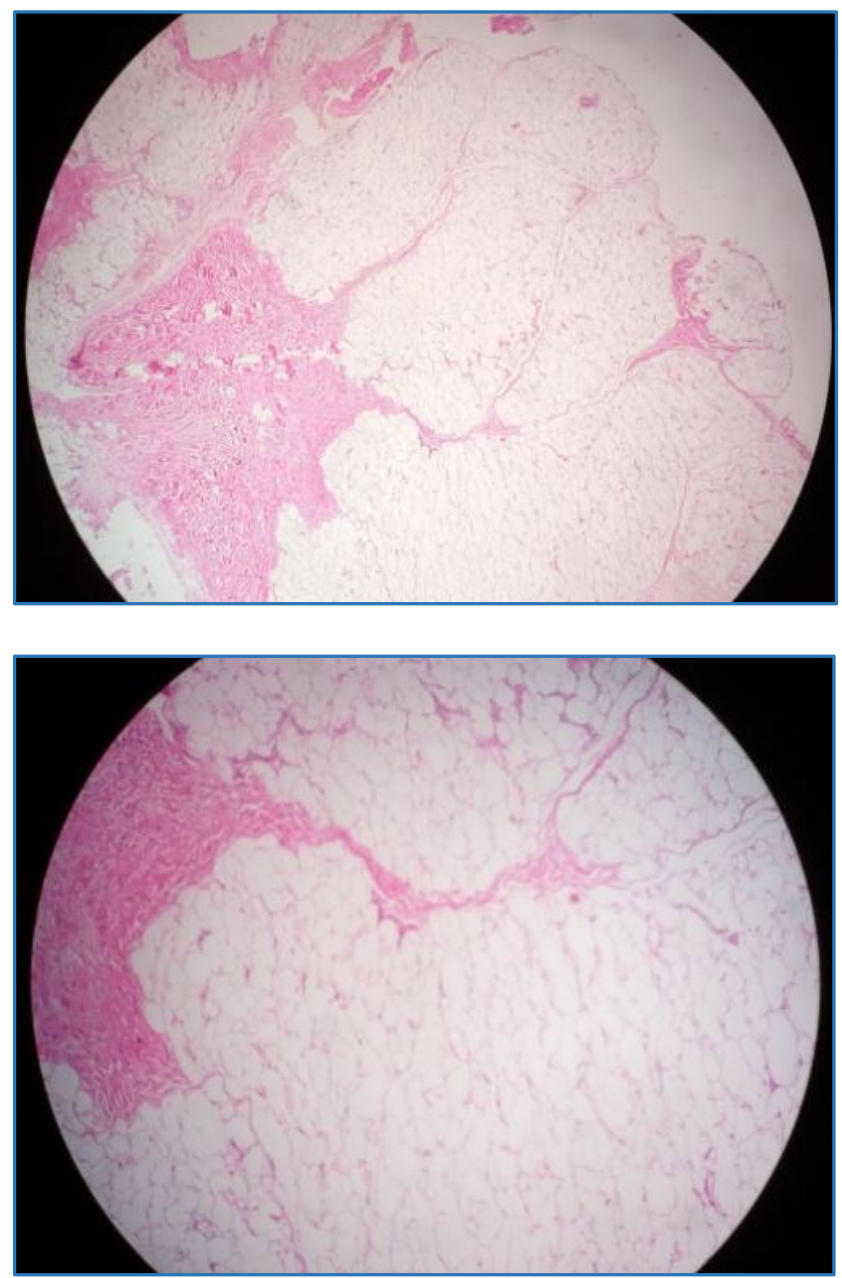

Fig. 3: $H$ and $E$ Stain Pictures with $4 X$ and $10 X$ Magnifications.

The postoperative period was uneventful. The patient will need a second stage reconstruction of the left big toe.

\section{DISCUSSION}

\section{Classification of Macrodactyly}

True macrodactyly involves hypertrophy of all the structures of the digit: the skin, toenail, subcutaneous fat, bones, nerves, and blood vessels.[4] Metacarpals, metatarsals, tendons, and veins in the digits are not affected. However, the involvement of metacarpals and metatarsals have also been reported. False macrodactyly presents as hypertrophy of primarily one tissue type.[5]

\section{Another Classification of Macrodactyly is}

- $\quad$ Static and

- $\quad$ Progressive.

The more common is static type showing enlargement from birth and increases in size proportional to the growth of the child. In static macrodactyly, the deformity is present in infancy and is usually have diffuse enlargement of the digit. 
The distal and palmar tissues appear more enlarged than the dorsal and proximal tissues. The fingers grow in proportion to normal digital growth. In progressive macrodactyly, the digits may not enlarge during infancy, but begin to enlarge rapidly during early childhood frequently with an annular deformity that makes the finger banana shaped. Pedal macrodactyly tends to be mostly of the progressive type. The clinical course of overgrowth in macrodactyly is important for prognostic and therapeutic reasons. In the progressive form, the digit begins to grow faster than the normal early childhood growth. An overgrowth of tissues of the digits and the appendages may also be noted.

\begin{tabular}{|c|c|c|}
\hline Subtype & $\begin{array}{l}\text { Associated } \\
\text { Conditions }\end{array}$ & $\begin{array}{c}\text { Distinguishing } \\
\text { Features }\end{array}$ \\
\hline $\begin{array}{c}\text { True } \\
\text { Macrodactyly }\end{array}$ & $\begin{array}{l}\text { Proteus } \\
\text { syndrome }\end{array}$ & $\begin{array}{l}\text { Connective tissue nevi, } \\
\text { epidermal nevi, } \\
\text { disproportionate growth }\end{array}$ \\
\hline \multirow[t]{6}{*}{$\begin{array}{c}\text { False } \\
\text { Macrodactyly }\end{array}$} & $\begin{array}{l}\text { Ollier's } \\
\text { disease }\end{array}$ & $\begin{array}{l}\text { Enchondromatosis, } \\
\text { cerebral tumours }\end{array}$ \\
\hline & $\begin{array}{l}\text { Maffucci's } \\
\text { syndrome }\end{array}$ & $\begin{array}{l}\text { Enchondromatosis, } \\
\text { haemangioma }\end{array}$ \\
\hline & $\begin{array}{l}\text { Milroy's } \\
\text { disease }\end{array}$ & Congenital lymphedema \\
\hline & $\begin{array}{l}\text { Klippel- } \\
\text { Trenaunay } \\
\text { syndrome }\end{array}$ & $\begin{array}{l}\text { Port wine haemangioma, } \\
\text { varicose veins, soft } \\
\text { tissue/bone } \\
\text { hypertrophy }\end{array}$ \\
\hline & $\begin{array}{c}\text { Vascular } \\
\text { malformati } \\
\text { on }\end{array}$ & \\
\hline & $\begin{array}{c}\text { Neurofibro } \\
\text { matosis }\end{array}$ & \\
\hline \multicolumn{3}{|c|}{$\begin{array}{c}\text { Table 1: Classification of Macrodactyly } \\
\text { with Associated Conditions }\end{array}$} \\
\hline
\end{tabular}

Macrodactyly affects the fingers more frequently than the toes. [6,7] Concurrent involvement of upper and lower extremity involvement being extremely rare.[8] In the foot, macrodactyly usually presents in the first, second, or third digit; the second digit is most frequently involved.[9,10] When overgrowth of an adjacent digit is also present, syndactyly is not unusual. The differential diagnosis for macrodactyly include a variety of conditions associated with hypertrophy due to neurofibromatosis, Albright's dysplasia, Lymphangioma, arteriovenous fistula, fibrous dysplasia, Sturge-Weber syndrome, and proteus syndrome. A variety of syndromes are described along with macrodactyly. [Table: 1].

\section{The Theories of Pathogenesis of Macrodactyly Include}

- Lipomatous degeneration.

- Neurofibromatosis.

- Nerve dysfunction.

- In-utero disruption of growth-limiting factors.

Pathologically, there is unusual large nerve size associated with infiltration with fatty tissues and the fatty tissue resembles that of adult fat tissues is characteristic of macrodactyly. Radiological findings include advanced bony development, over-growth of fatty tissue, and larger than normal-sized digital arteries. Clinically, there is enlargement of digits with thickened skin and stiff joints are seen.

Although, macrodactyly occurs as an isolated congenital defect. It is associated with neurofibromatosis, Klippel-
Trenaunay-Weber syndrome, hemihypertrophy, hemangiomatosis arteriovenous fistula, lymphangiomatosis, and congenital lipofibromatosis. A review of literature of showed the actual diagnosis of true or primary macrodactyly [Table. 2].

\section{Surgical Options}

A variety of surgical options are available for the treatment of macrodactyly. A combination of procedures in well selected patients in the proper age of the child yields good results.

\section{The following options is available}

- Phalangeal resection.

- Phalangeal amputation.

- Syndactylization.

- Digit shortening.

- Tissue debulking procedures.

- Osteotomy.

- Amputation.

- Epiphyseal plate arrest.

\section{Molecular Genetic basis of Macrodactyly}

Barsky postulated that "Macrodactyly is the result of interaction of two or more intrinsic and extrinsic agents (Genetic and/or environmental) each unable to produce the deformity itself". He further added that during fetal development some disturbance of growth-limiting factor occurs in the affected local area, which continues to increase in size. There are two concepts of formation of macrodactyly namely

- Association with neurofibromatosis.

- Basic process is lipomatous degeneration.

\begin{tabular}{|c|c|c|c|c|}
\hline $\begin{array}{c}\text { Sl. } \\
\text { No. }\end{array}$ & Author & $\begin{array}{c}\text { Review } \\
\text { Period }\end{array}$ & Total & $\begin{array}{c}\text { Lower } \\
\text { Limb }\end{array}$ \\
\hline 1 & $\begin{array}{c}\text { De Valentine } \\
\text { et al }\end{array}$ & $\begin{array}{c}\text { Mid } \\
1978\end{array}$ & 74 & 29 \\
\hline 2 & Kalen et al & 1988 & 167 & 52 \\
\hline 3 & Annandale & 1866 & $\begin{array}{l}\text { First podiatric medical } \\
\text { case of bilateral } \\
\text { macrodactyly of big } \\
\text { toes }\end{array}$ \\
\hline 4 & $\begin{array}{c}\text { Barsky } \\
\text { (1967) }\end{array}$ & $\begin{array}{c}1827- \\
1967 \\
(140 \\
\text { years) }\end{array}$ & $\begin{array}{l}\text { 56 cases of true or } \\
\text { primary macrodactyly } \\
\text { and 8 cases added by } \\
\text { him }\end{array}$ \\
\hline \multicolumn{4}{|c|}{ Table 2: Review of Literature of Macrodactyly } \\
\hline
\end{tabular}

Brooks and Lehman believed that neurofibromatosis of periosteal nerves is the main cause of rapid localized overgrowth.[11] They stated "We know of no other condition in which there is a spontaneous excessive growth in length of a single bone other than Von Recklinghausen's disease". Moore forwarded the strongest argument in favour of the view that neurofibroma is the cause of the hypertrophy after his observation that there is a definitive segmental relationship between the affected nerve and the overgrowth.[12] Inglis suggested that the enlargement was influenced by the neurointrinsic factor of neurofibromatosis acting locally.

He demonstrated a strikingly similar pathologic picture between the neural enlargement of macrodactyly and section of terminal branches of proved cases of neurofibromatosis.[13] 
However, Thorne et al., in their study of thirteen cases did not find any evidence of neurofibromatosis. ${ }^{[14]}$ Feriz coined the term macrodystrophia lipomatosa progressiva after his observation of excessive proliferation of fat in pedal macrodactyly.[15] Somatic mutation in PIK3CA was observed in all the 18 macrodactyly patients in a series. The mutational frequency was observed to be greatest in nerve. Mutations were not found in control polydactyly tissue or the blood of macrodactyly patients. Mutations leading to altered potassium channel function was identified in mutagenesis screening in zebra and fish with long fins was demonstrated. Analogous gain-of-function variants in the same potassium channel gene were identified in $6 / 18$ macrodactyly patients and in 5/6 patients with a clear median nerve territory distribution.

\section{Management of Macrodactyly}

Conservative treatment methods include foot lifts, padding, and customized shoes may be somewhat beneficial, but they often provide only limited long-term relief.[16]

\section{Surgical Procedures for Macrodactyly}

Surgery is the primary treatment for these conditions. ${ }^{[17]}$ and should be approached with the goals of surgery are improving ambulation and obtaining a painless plantar grade foot that is similar in length and width of the contra lateral foot that is cosmetically acceptable and can fit into a shoe.[18,19]

1. Debulking or defatting: Is the most commonly attempted procedure and involves bulk reduction of the involved soft tissue. When used alone it is not sufficient for size reduction and only provides short-term success. It is only indicated in children and according to Kotwal et al in 1998, needs to be followed by another debulking procedure within 3 months.

2. Phalangectomy: Involves shortening of the affected toe and successfully decreases the length of the affected ray by Barsky, Tsuge, Kotwall, and Farooque.

- Barsky performed the phalangectomy and then by arthrodesis.

- $\quad$ Tsuge by distal phalanx removal with dorsal flap while.

- Kotwal and Farooque by middle phalanx removal.

3. Amputation: The metatarsal spread angle is a crucial indicator for affected ray resection. In the lesser rays of the foot, a metatarsal spread angle of 10 or less is a good indicator for a debulking procedure and repeated diaphyseal shortening. In the severe case where the metatarsal spread angle is greater than 10 , a ray resection is indicated.

4. Surgery of the First Ray: First Ray resection is never an option due to biomechanical importance during gait and cosmesis i.e., nail preservation. ${ }^{[20]}$ Reconstructive surgery is therefore indicated.[21,22] Island nail flap in the treatment of foot macrodactyly of the first ray in children.[23]

5. Epiphysiodesis in Macrodactyly: Macrodactyly is a congenital condition, which may impede the development of normal gait. Epiphysiodesis is used to arrest growth, especially in the hallux, which is important for normal gait and weight bearing. Correction of macrodactyly with epiphysiodesis is usually done at a young age, but the exact timing depends on the severity of the malformation. The aim for correcting macrodactyly is not only cosmesis, but also to accommodate regular shoes. Preoperatively, there is a consideration of clinical symptoms and disturbance to gait and overall quality of life. Treatment is based on predicted correction at the age of maturity. This predicted value is determined by projections produced by various equations and charts based on the patient's skeletal age and maturity. Due to the fact that epiphysiodesis is a technique that uses the natural progression of bone growth. It is imperative that this procedure is done at the correct time to ensure full correction and avoid over correction. This timing is determined by four basic methods (1) the multiplier, (2) the growth remaining, (3) the straight line graph, and (4) the arithmetic methods.

\section{Differential Diagnosis of Macrodactyly}

Overgrowth conditions may be grossly apparent or present with subtle clinical finding. Early recognition with focused history and clinical evaluation are required to determine the extent and severity of the overgrowth condition. Associated conditions should also be noted and appropriate consultations should be made as necessary. If the overgrowth is limited to a digit or ray, macrodactyly may initially be suspected. An enlarged digit will be incorrectly diagnosed as macrodactyly.[24], so a focused examination is required with consideration of differential diagnoses. History of trauma may be suggestive of hematoma. Radiographs and computed tomography (CT) can differentiate from an osseous neoplasm. Soft tissue neoplasms are best ruled out with a magnetic resonance imaging (MRI).[25] MRIs and radiographs also allow for assessment of the tissue type and consistency of an overgrowth. Thus, these imaging techniques are useful in differentiating true from false macrodactyly.

Macrodactyly may present unilaterally or bilaterally and symmetrically or asymmetrically; a bilateral condition can be differentiated from hemihyperplasia, which is unilateral, by definition. A thorough history provided by the young patient's parents should be acquired. The initial presentation of the condition and the course of progression can indicate whether a macrodactyly is of the static or progressive form. Circumferences and lengths measurement of the involved and uninvolved sides is done to assess the static or progressive form of macrodactyly. If progressing, the measurements can be used to calculate the rate of progression.

Bone Length Ratios of the First Ray and Second Digit Camasta's morphometric analysis suggests the analogous first ray and second digit consistently have segments of the same proportions. The bone length ratio of 0.75:1.0:2.0 describes the lengths of the distal: middle: proximal segments. Aberrations in the length ratios reveal a dysmorphic condition. The growth plates in the first, third, and fourth metatarsals give the clinical appearance of a large second metatarsal. In this case, the relatively large metatarsal was normal and not an overgrowth deformity.

The same consideration should be made when evaluating a unilateral overgrowth of the entire foot or limb. 


\section{Histopathological Examination}

Histopathological examination of involved skin of macrodactyly show flattening of rete pegs associated with an excessive deposition of connective tissue. Histological section show hypertrophied adipose tissue interspersed with collagen fibers. Lobules of fat were noted to be unusually large resembling adult fat. The pathologic substrate of macrodactyly is hypertrophy of the bone with hamartomatous overgrowth of predominantly lipomatous or fibrous tissues. Histopathologic findings suggest that in macrodactyly of the foot excessive proliferation of adipose tissue is the basic aetiology whereas in the hand hypertrophy and tortuosity of the digital nerves are the predominant findings. Lipomatous degeneration and disturbances of fetal circulation or local growth promoting or inhibiting factors have also been postulated as common causes of macrodactyly.

\section{Postoperative Complications}

Are noted according to the procedure type. Following epiphysiodesis, segmental or complete resection of the phalanx, digit amputation, and debulking the common complications include, infection, necrosis, and stiffness in the proximal interphalangeal joint.

\section{Complications reported with Amputation of the Second toe include \\ - Hallux valgus. \\ - Similar angular deformities. \\ - Scar contraction. \\ - Recurrence of growth.}

\section{General Complications following Macrodactyly are}

- Wound dehiscence.

- Prolonged oedema.

- Sensory disturbances.

\section{CONCLUSION}

In macrodactyly, hands and feet are affected with almost equal frequency. In both hands and feet, the highest incidence is of second digit involvement followed by third digit enlargement. Involvement of more than one digit is common. It is important to diagnose the condition and institute the correct treatment at the appropriate age of the patient. The long drawn process of treatment and rehabilitation may be frustrating to the patient. Psychological support is required for most of the patients. Genetic screening and genetic counseling provide us with an insight into the understanding of the nature of the macrodactyly.

\section{REFERENCES}

1. Barsky AJ. Macrodactyly. J Bone Joint Surg 1967;49(7):1255-66.

2. Bulut M, Karakurt L, Belhan O, et al. Ray amputation for the treatment of macrodactyly in the foot: report of three cases. Acta Orthop Traumatol Turc 2011;45(6):458-62.

3. Kalen V, Burwell DS, Omer GE. Macrodactyly of the hands and feet. J Pediatr Orthop 1988;8(3):311-15.

4. Dennyson WG, Bear JN, Bhoola KD. Macrodactyly in the foot. J Bone Joint Surg Br 1977;59(3):355-9.
5. Boberg JS, Yu GV, Xenos D. Macrodactyly: a case report. J Am Pod Med Assoc 1985;75:41-5.

6. De Greef A, Pretorius LK. Macrodactyly: a review with a case report. S Afr Med J 1983;63(24):939-41.

7. De Valentine S, Scurran BL, Tuerk D, et al. Macrodactyly of the lower extremity: a review with two case reports. J Am Pod Med Assoc 1981;71:175-80.

8. Keret D, Ger E, Marks H. Macrodactyly involving both hands and both feet. J Hand Surg Am 1987;12(4):610-14.

9. Chang $\mathrm{CH}$, Kumar SJ, Riddle EC, et al. Macrodactyly of the foot. J Bone Joint Surg Am 2002;84-A(7):1189-94.

10. Brooks B, Lehman EP. The bone changes in Recklinghausen's neurofibromatosis. Surgery, Gynaecology and Obstetrics 1924;38:587-95.

11. Moore BH. Macrodactyly and associated peripheral nerve changes. J Bone Joint Surg 1942;24:617-31.

12. Inglis K. Local gigantism, a manifestation of neurofibromatosis: its relations to general gigantism and to acromegaly; illustrating the influence of intrinsic factors in diseases when development of the body is abnormal. Am J Pathol 1950;26(6):1059-83.

13. Thorne FL, Posch JL, Maldick RA. Megalodactyly. Plast Reconstr Surg 1968;41(3):232-9.

14. Feriz H. Macrodystrophia lipomatosa progressiva. Virchow's Archiv fuer pathologische Anatomie und Physiologie und fuer klinische Medizin 1926;260:308-68.

15. Wagreich CR. Congenital deformities. In: Banks AS, Downey MS, Martin DE, eds. McGlamry's Forefoot Surgery (Biopsy Interpretation Series). $1^{\text {st }}$ ed. Lippincott Williams \& Wilkins 2004:487-511.

16. Hop MJ, van der Biezen JJ. Ray reduction of the foot in the treatment of macrodactyly and review of the literature. J Foot Ankle Surg 2011;50(4):434-8.

17. Perdiue R, Mason WH, Bernard TN. Macrodactyly: a rare malformation: review of the literature and case report. J Am Podiatry Assoc 1979;69(11):657-64.

18. Uemura $\mathrm{T}$, Kazuki $\mathrm{K}$, Okada $\mathrm{M}$, et al. A case of toe macrodactyly treated by application of a vascularised nail graft. Br J Plast Surg 2005;58(7):1020-4.

19. Dautel G, Vialaneix J, Faivre S. Island nail transfer in the treatment of macrodactyly of the great toe: a case report. J Foot Ankle Surg 2004;43(2):113-8.

20. Downey-Carmona FJ, Lagares A, Farrington-Rueda D, et al. Island nail flap in the treatment of foot macrodactyly of the first ray in children: report of two cases. J Child Orthop 2015;9(4):281-5. DOI 10.1007/s11832-015-0670-z.

21. D'Costa H, Hunter JD, O'Sullivan G, et al. Magnetic resonance imaging in macromelia and macrodactyly. $\mathrm{Br} \mathrm{J}$ Radiol 1996;69(822):502-7.

22. McDonald JF, Pruzansky JD, Meltzer RM. Evaluation of recurrent macrodactyly with three-dimensional imaging. J Am Pod Med Assoc 1991;81:84-7.

23. Sharma S, Vyas S, Sood RG, et al. Macrodactyly: report of report of 3 cases. Ind J Radiol Imag 2006;16(4):583-4.

24. Gupta SK, Sharma OP, Sharma SV, et al. Macrodystrophia lipomatosa: radiographic observations. $\mathrm{Br} \mathrm{J}$ Radiol 1992;65(777):769-73.

25. Kotwal PP, Farooque M. Macrodactyly. J Bone Joint Surg Br 1998;80(4):651-3. 